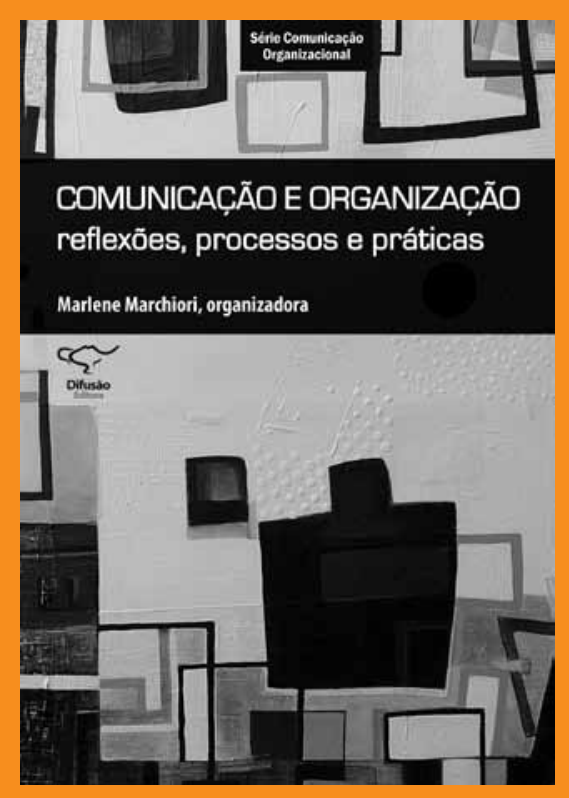

Comunicação e organização: reflexões, processos e práticas

Marlene Marchiori (Org.)

São Caetano do Sul, SP:

Difusão Editora, 2010

352 páginas

Resenhado por:

Ricardo Caribé

- Doutorando e mestre em Administração pela UFBA

- Graduado em Relações públicas

- Coordenador do Curso de Pós-graduação em Gestão da Comunicação Organizacional Integrada da Universidade Católica de Salvador (UCSal)

- Diretor da Tábuas da Ponte Comunicação Organizacional

- ricardo@tabuasdaponte.com.br 


\section{Encontrando caminhos entre a comunicação e os estudos organizacionais}

\section{Finding paths between communication and organizational studies}

\section{Encontrando caminos entre la comunicación y los estudios organizacionales}

Ose s bons livros organizados ou coletâneas, como também são conhecidos, se caracterizam por oferecer aos leitores interessados naquele determinado tema a oportunidade de ver reunida uma diversidade de textos e autores de alto nível, recheada com conteúdo verdadeiramente significativo. Há, contudo, formas distintas para se chegar a esse resultado (sem deméritos de importância ou qualidade para cada uma delas). Alguns organizadores reúnem em sua obra o que há de mais relevante em termos de proposição teórica na área específica do conhecimento, oferecendo assim aos leitores verdadeiros tratados de referência, sobretudo para quem ingressa no campo ou inicia esforços de revisão bibliográfica. Outros mesclam autores renomados, com o objetivo de destacar os contrastes e as complementaridades entre eles e oportunizar o contato de neófitos com os vip's (very important people) do campo - uma espécie de degustação de seus pensamentos. Há, ainda, os que resgatam o contraste de experiências práticas relevantes e distintas, como que a constituir painéis impressionantes, de grande valor didático (são, de um lado, orientação técnica de conduta; e do outro, possibilidade de se refletir comparativamente sobre a vida real). Marlene Marchiori, na obra por ela organizada, Comunicação e organização: reflexões, processos e práticas, ambiciona e consegue mesclar os três caminhos, obtendo como resultado uma obra robusta e versátil, de valor destacado, sobretudo (mas não somente), para o campo da comunicação organizacional.

O livro se destina ao enfrentamento das delimitações de campo - notadamente, administração e relações públicas; estudos organizacionais e comunicação organizacional - e cumpre muito bem esse papel, impulsionando e dando contribuição efetiva aos estudos multidisciplinares do fenômeno social da comunicação organizacional. Aliás, por falar nisso, o brilhante prefácio de Miguel Caldas bem que poderia ser considerado como mais um importante capítulo da obra, que foi divida pela organizadora em três partes:. a primeira, "O olhar 
sobre a comunicação e organização”, com seis capítulos, dedicada a proposições teóricas; a segunda, "Comunicação e seus processos na organização", com sete capítulos, que pretende concentrar-se em processos de comunicação; e a terceira, "Comunicação e suas práticas nas organizações", com três capítulos, mescla o olhar histórico e autocompreensivo de organizações com destacada lição de vida organizacional.

Não obstante, uma outra classificação dos dezesseis trabalhos poderia ser proposta, a bem da nossa crítica: um primeiro grupo reúne contribuições teóricas efetivas ao campo da comunicação organizacional. Dele fazem parte os trabalhos de João Marcelo Crubellate e Hilka Machado ("Organizações e ambiente organizacional: uma abordagem neofuncionalista"); James Taylor e Adriana Casali ("Comunicação: o olhar da Escola de Montreal sobre o fenômeno organizacional”); Stanley Deetz ("Comunicação organizacional: fundamentos e desafios)"; Gail Fairhurst e Linda Putnam ("Organizações como construções discursivas"); e Fabio Vizeu ("Poder, conflito e distorção comunicativa nas organizações contemporâneas"). Esse repertório, parte mais destacada de toda a obra, coloca o leitor diante de perspectivas teóricas com forte conotação crítica e humanística, representativas de parte destacada do pensamento contemporâneo - norte-americano e europeu - sobre teoria social, organizacional e comunicacional. Além da Escola de Montreal e das concepções de referência de Stanley Deetz, chama a atenção o trabalho do brasileiro Fabio Vizeu diante da dificílima missão de apropriar a teoria social de Jürgen Habermas (expressa, entre outras, em sua obra máxima Teoria da ação comunicativa) para a reflexão e ação no campo da comunicação organizacional.

O segundo bloco reúne trabalhos que se valem de fundamentos teóricos diversos (citados ou não nos demais capítulos da obra) para apreciar e discorrer sobre objetos da ordem do dia do campo empresarial: estratégia, inovação, desempenho, comunicação interna, relacionamento. Nele predominam argumentações em prol de abordagens práticas e reflexivas, muitas delas em pleno debate no campo da comunicação organizacional brasileira, expressas por seus autores em artigos recentes ou em outras importantes publicações nacionais. Os pontos altos desse grupo de textos recaem sobre as contribuições à gestão estratégica de stakeholders dada por Ana Luisa Almeida e Janete Lara Bertucci, extremamente interessante para executivos e acadêmicos; e sobre o mineiríssimo texto de Alexandre Carrieri, dedicado à dinâmica da produção simbólica cotidiana nas organizações, simples e ao mesmo tempo denso e de grande riqueza.

O terceiro e menor bloco poderia se chamar, com alguma licença, de estudos de caso. Mas não se trata de quaisquer casos. São relatos de organizações complexas e grandiosas, em cujas experiências se refletem muitos dos grandes desafios teóricos e práticos da comunicação organizacional. Paulo Nassar ("Uma evolução da comunicação organizacional brasileira no contexto da administração"); Marcio Polidoro ("Odebrecht: a comunicação como processo 
e a construção de culturas"); e Olinta Costa ("Desafios do diálogo no relacionamento com comunidades: a experiência da Vale") dão, com seus textos e ao seu modo, substantiva contribuição a essa obra valorosamente miscigenada.

A obra certamente agradará bastante a uma parcela do público leitor que aprecia a combinação de textos teóricos com outras modalidades de contribuição ao campo da comunicação organizacional. Contudo, aos que anseiam pelo avanço dos estudos multidisciplinares de organizações e de comunicação - inclusive com a ampliação do acesso (em português) ao pensamento de renomados autores estrangeiros, ao lado da já significativa produção teórica brasileira - pode restar a sensação de que o livro de Marlene Marchiori é um valioso estímulo inicial, que certamente terá outros desdobramentos positivos, dando sequência ao trabalho inestimável que a autora, como acadêmica reconhecida nacional e internacionalmente, iniciou em suas obras anteriores e que se continua com Comunicação e organização: reflexões, processos e práticas. 